\title{
Welfare-to-Work Reforms: Impact on Sole Parents
}

\author{
Ann Harding, Quoc Ngu Vu, Richard Percival \\ and Gillian Beer
}

I

$\mathrm{n}$ recent years, the labour force participation rate of sole parents has been of growing concern in Australia and in some overseas countries. Wilson, Pech and Bates (1999:4), for example, showed that the labour force participation rates of sole parent mothers remained about 10 per cent lower than those of partnered mothers during the 1990s. While their analysis suggested a marginal increase in the labour force participation rates of both groups during the 1990s, it is clear that the pronounced increases in female labour force participation rates have been due primarily to growing participation by women without children. The labour force participation rates of sole parent fathers, while higher than for sole parent or partnered mothers, are still well below those of partnered fathers.

The creation of new longitudinal datasets has challenged the perception of mobility among the sole parent pensioner population. For example, Barrett (2001) analysed four years of longitudinal data and found that 18 per cent of recipients were 'short-term' and received Parenting Payment Single (PPS) for six months or less; 15 per cent remained on the program for the entire four years and 25 per cent experienced multiple episodes of Parenting Payment Single receipt, thus cycling on and off the program. Using similar data, Gregory and Klug (2003:21) found that, while it was difficult to be precise, 'the average cumulative use of income support over the period for which parents have dependent children may be as much as 12 years'. They found that sole parents frequently cycle through different income support payments, moving from PPS to Parenting Payment Partnered and back again.

This has raised concerns that the current structure of Parenting Payment Single may be a 'tender trap', promoting long-term dependence on welfare and discouraging active participation in the labour market and the community (Saunders and Tsumori, 2003). Low labour force participation has adverse consequences both during the prime age years and later in life during retirement. Research by NATSEM and AMP, for example, has shown that the savings of many baby boomers are not sufficient to finance a comfortable retirement. The problem is particularly acute for baby boomer women and sole parents (Kelly and Harding, 2002; Kelly, Percival and Harding, 2002; Kelly, Farbotko and Harding, 2004). As a result, in Australia and New Zealand, 'the direction of policy has moved towards promoting self-reliance through paid work' (Goodger and Larose,

Ann Harding is Professor of Applied Economics and Social Policy and inaugural Director of NATSEM, University of Canberra. Quoc Ngu Vu is a senior research officer and Richard Percival and Gillian Beer are principal research fellows at NATSEM. 
2005:1). Bradbury (2003:18) notes that 'many countries are turning to employment as the solution to child poverty'.

The emergence of labour force shortages in Australia has been an additional concern, accompanied by two key government reports suggesting lower rates of labour force participation and economic growth in the future due to population ageing (Treasury, 2002; Productivity Commission, 2005). Increasing labour force participation rates has thus moved very firmly onto the policy agenda.

With one in five marriages ending before 10 years (Kelly and Harding, 2005) another issue has been the growth in the number of sole parent families. In 2003, 543,000 or about 22 per cent of all families with children aged 0 to 17 years were sole parent families. This was up from 17 per cent in 1992. One-fifth of Australian children now live in sole parent families (ABS, 2004:6). As Bradbury (2003:34) notes, 'having only one workforce-age parent available, whose employment is constrained by caring responsibilities, means that children living in lone-parent households are almost inevitably more likely to be poor'. Internationally, Australia has relatively high child poverty levels, both for children generally and for children in sole parent households (p. 45). In the late 1990s, a national ABS survey found that 41 per cent of sole parent households reported high levels of financial stress - higher than for any of the other family types considered (McColl, Pietsch and Gatemby, 2002:12).

These issues are of particular concern to policy makers, with the development of the Federal Government's National Agenda for Early Childhood reflecting research suggesting that adverse childhood experiences have a profound impact on the rest of a child's life. Children experiencing multiple forms of social and economic disadvantage are more likely to have poor health and well-being. The adverse effects persist throughout their lives and include lower subsequent rates of educational and labour market achievement and a greater likelihood of becoming teenage parents and serving prison sentences (Poulton et al, 2002; UNICEF, 2000; Moore et al, 2002; Burgess and Propper, 1998).

Against this backdrop, in the May 2005 Budget the Federal Government announced a range of proposed welfare to work measures, including significant changes for sole parents, to take effect from 1 July 2006. Currently, sole parents with a qualifying child aged less than 16 years who meet various income and asset tests can receive PPS subject to the pension income test and payment rate rules. Sole parents in receipt of PPS prior to 1 July 2006 will continue to remain on that payment and be subject to the 'pension' income test (which is more generous than the 'allowance' income test), until their youngest child turns 16. However, new compulsory work obligations will be imposed on this group from the later of 1 July 2007 or when their youngest child turns six. These new obligations will be satisfied by working part time for a minimum of 15 hours a week or by searching for part-time work and participating in Job Network or other services.

There are more significant changes for sole parents applying for PPS after 1 July 2006. Sole parents with a child aged less than six years will still be eligible to receive PPS. However, as soon as their youngest child turns six, they will be transferred to Newstart Allowance (NSA) and be subject to an obligation to seek 
part-time work of at least 15 hours per week. NSA provides a lower payment rate than PPS and has a much less generous income test. As a result, many sole parents will be facing large falls in income when their youngest child turns six and, for those whose youngest child is already aged six to 15 years, the returns from paid work will be much lower than currently.

The rest of the paper begins with an explanation of the likely new payment structures applying to sole parents in 2006-07. The likely falls in the disposable (after-income-tax) income of affected sole parents, relative to payments under the current program rules, are presented in the subsequent section. The next section examines the impact of the reforms on the effective marginal tax rates of affected sole parents. Conclusions are presented in the final section.

\section{The Parenting Payment Single and Newstart Allowance Programs}

As they depend upon future trends in average weekly earnings and the consumer price index, there is inevitable uncertainty about the exact payment rates for NSA and PPS that will apply in 2006-07. The following estimates are based on NATSEM's latest projections of these indexes. The modelling is also based on current Government statements about the structure of income support after 1 July 2006 (Andrews, 2005a,b). However, at the time of writing this article, the legislation is yet to be introduced, so some of the programs and parameters used in the modelling may be changed.

PPS for sole parents with one child and no private income is expected to be about \$257 a week on average in 2006-07 (Table 1). A crucial factor is the amount of private income that can be earned before the income support payment is reduced. In 2006-07, a sole parent with one child on PPS will be able to earn \$76 a week without incurring a reduction in income support. For every dollar of income earned above this threshold, the support payment is reduced by 40 cents. Sole parents with a youngest child aged less than six years, applying for PPS after 1 July 2006, will be subject to this payment rate and income test.

Sole parents with a youngest child aged six years and over will be placed on NSA, which is expected to average \$228 a week in 2006-07. This is \$29 a week less than the PPS payment rate. In addition, they will be able to earn only $\$ 31$ a week before their income support payment begins to be reduced. That is, their 'free area' will decline sharply relative to the current rules, by about $\$ 45$ a week. The first $\$ 94$ of private income above $\$ 31$ a week will reduce their NSA by 50 cents for every dollar earned. Once they reach the second income test threshold of $\$ 125$ a week, the reduction in their allowance increases to 60 cents for each additional dollar earned. In other words, once private income reaches \$125 a week, they will keep only 40 cents of each additional dollar earned, until they reach the allowance 'cut out point'.

The NSA income test is thus much more restrictive than the PPS income test, and this is reflected in the very different 'cut out points' shown in Table 1. Sole parents with one child on PPS will be able to earn up to around $\$ 718$ per week before their income support cuts out. On the NSA their entitlement to income 
support is extinguished with earnings of about $\$ 426$ a week. This means that income support will cease at a much lower level of earnings for those subject to the new NSA test than for those on the existing PPS. For those with more than one child the difference will be even greater, as the 'free area' for PPS is increased by a further $\$ 12.30$ per child per week for each child after the first, whereas the 'free area' under NSA does not vary with the number of children.

Table 1: Summary of the Newstart Allowance and Parenting Payment Single Payments for Sole Parents with One Child, 2006-07 ${ }^{\mathbf{a}}$

\begin{tabular}{|c|c|c|c|}
\hline & $\begin{array}{c}\text { Parenting } \\
\text { Payment Single }\end{array}$ & $\begin{array}{c}\text { Newstart } \\
\text { Allowance }\end{array}$ & Difference \\
\hline & \multicolumn{3}{|c|}{$\$ p w$} \\
\hline Payment rate for those with one child & $\$ 257$ & $\$ 228^{b}$ & $-\$ 29$ \\
\hline $\begin{array}{l}\text { Amount of income that can be earned } \\
\text { before payment is reduced }\end{array}$ & $\$ 76$ & $\$ 31$ & $-\$ 45$ \\
\hline $\begin{array}{l}\text { Withdrawal rate for each } \$ \text { of private } \\
\text { income above this threshold }\end{array}$ & $40 \%$ & $50 \%$ & $+10 \%$ \\
\hline Second income test threshold & na & $\$ 125$ & \\
\hline $\begin{array}{l}\text { Withdrawal rate for each } \$ \text { of private } \\
\text { income above this threshold }\end{array}$ & $40 \%$ & $60 \%$ & $+20 \%$ \\
\hline $\begin{array}{l}\text { Income support cuts out when private } \\
\text { income reaches this point (cut-out point) }\end{array}$ & $\$ 718^{C}$ & $\$ 426^{c}$ & $\$ 292$ \\
\hline
\end{tabular}

Notes: a These are the estimated averaged payment rates and thresholds that will apply in 2006-07. The actual payment rates vary at various points throughout the financial year, in line with indexation arrangements. All figures rounded to nearest whole dollar.

b This includes $\$ 2.90$ a week of Pharmaceutical Allowance (PA), which the government has said will also now be paid to NSA recipients who are sole parents.

C This includes the effect of the $\$ 2.90$ a week of PA.

Source: Specially created version of STINMOD/05A

Sole parents receiving NSA will also be affected adversely by other, less obvious, factors. One is that pensioners (including PPS recipients) qualify for the Pensioner Tax Offset. The aim of the tax offset is to ensure that no tax is payable by a pensioner whose assessable income consists of the pension and around $\$ 144$ a week of non-pension income. In 2006-07, some tax reduction will be received by PPS recipients whose taxable income is less than about $\$ 35,000$. In contrast, the Beneficiary Tax Offset (which ensures no tax is payable by maximum rate allowance recipients with up to $\$ 31$ a week of private income - and begins to be withdrawn when private income is above $\$ 31$ a week) means some tax reduction will be received by sole parent NSA recipients whose taxable income is less than about $\$ 27,500$. Thus, the reduction in income tax liabilities allowed is much greater for pensioners than for allowance recipients.

A second issue is the receipt of the Pensioner Concession Card (PCC). PPS recipients are automatically entitled to a PCC, which many organisations use as a 
'passport' to a range of price discounts for services such as property charges and taxes, energy, water, transport, education, health, car registration, housing and recreation services. While such services are often provided by State and local governments, many private sector businesses also charge lower prices to PCC holders. Similarly, many doctors offer bulk billing to PCC holders, so that they do not have to pay any additional co-payment.

The Government has stated that sole parents shifted to NSA under the proposed arrangements will retain the right to a PCC. However, as Table 1 makes clear, eligibility for NSA for sole parents will cease at a much lower level of private income than eligibility for PPS. As a result, there is a wide range of private income of almost $\$ 300$ a week over which sole parents formerly qualifying for the PCC apparently will not qualify under the new rules.

Most such sole parents will still receive a Health Care Card (HCC), via their receipt of maximum rate Family Tax Benefit Part A, but some concessions are provided by State and local governments and other organisations only to those with a PCC and not to those with a HCC. In Victoria, for example, PCC holders (but not HCC holders) qualify for a municipal rates concession of up to $\$ 160$ a year and a transport accident charge concession of up to about $\$ 170$ a year. Thus, the loss of these three items alone could reduce the effective income of some sole parents by some $\$ 6$ a week. However, the value to sole parents of the HCC or the PCC has not been included in the following analysis of their disposable incomes.

\section{Impact of Proposed Changes on Disposable Incomes}

Figure 1 traces the impact upon the disposable incomes of sole parents whose youngest child is aged six to 15 years and who would qualify for PPS under the current rules but will qualify for NSA under the proposed rules. That is, it shows the impact upon those sole parents who commence receipt of income support after 1 July 2006. For simplicity, the figure shows the estimated averages for the entire 2006-07 year rather than the precise point in the year at which sole parents become eligible for the payments. 'Disposable income' means the income that sole parents have left in their pockets to spend each week, after the receipt of any income support or private income, the payment of income tax and Medicare levy (net of the various tax allowances such as the pensioner tax offset and the low income tax rebate). The figure does not take any account of any possible child care costs or rebates or the possible impact of rising private income levels on such factors as consequent increases in public housing rents. The value of the PCC is also not included.

As Figure 1 shows, disposable incomes of sole parents with one child aged six years and over are much lower under the proposed system than under the current system over a very broad range of private income. ('Private income' means income other than government cash transfers.) The loss sustained by a sole parent amounts to almost $\$ 100$ a week when earnings are between about $\$ 200$ and $\$ 450$. As shown in Table 2, for example, the proposed reforms reduce the 'takehome' incomes of sole parents with one child and earnings of \$200 a week from 
$\$ 531$ under the current system to $\$ 439$ under the proposed system - a cut of $\$ 92$ a week. This effectively represents a 17 per cent cut in the living standards of these sole parents and their children. It should perhaps be mentioned again that cuts of this magnitude will be experienced almost overnight by sole parents at these private income levels when their youngest child turns six.

Figure 1: Disposable Income of Sole Parents with One Child 6 Years or Over Under Current and Proposed Systems, 2006-07

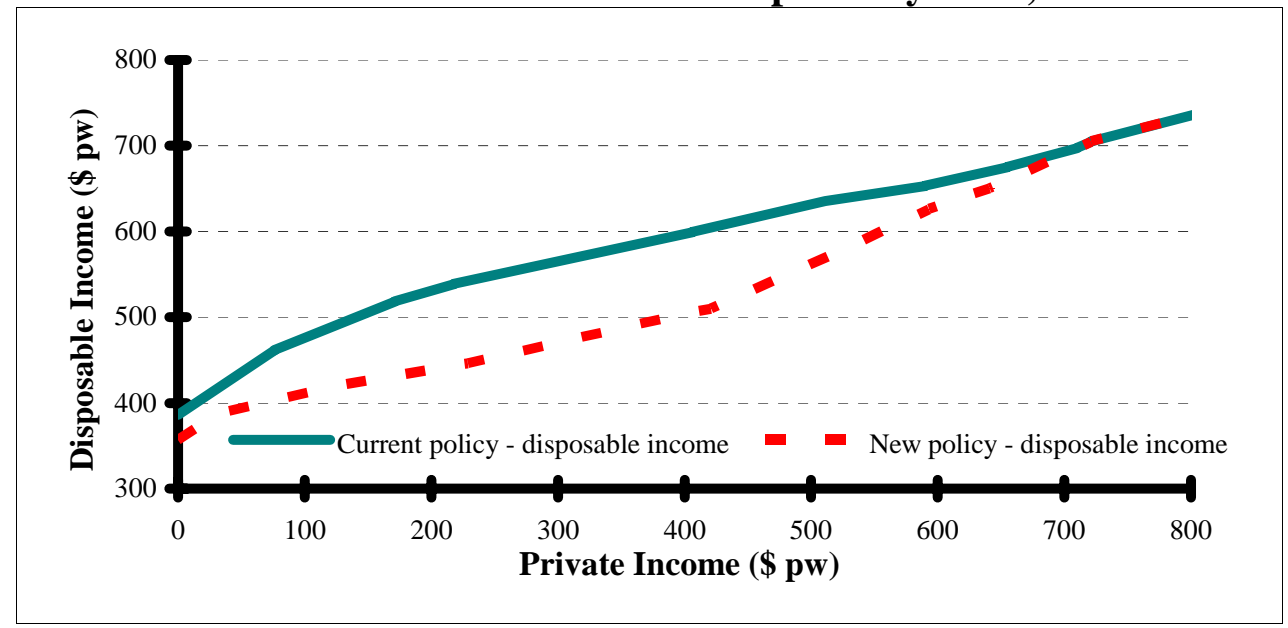

Source: Specially created version of STINMOD/05A. PA excluded from all calculations (see footnote to Table 2)

At low levels of private income, the difference of about a $\$ 30$ a week between the proposed and existing systems is due to the different maximum rates of pension and allowance. At the other end of the spectrum, above around $\$ 700$ a week, there is no difference in the incomes of sole parents under the proposed and current systems because, beyond this point, they are not receiving any income support. Between these points, disposable incomes of sole parents are lower under the new system than under the current system, primarily because of the stricter income test applying to NSA but also because of the less favourable tax concessions for allowance recipients compared with pensioners.

Sole parents with two and three children have higher disposable incomes than those with one child, due to their receipt of additional Family Tax Benefit Part A payments. Under the new system, at most income ranges, those with two and three children will experience slightly higher losses than those with one child. This is due to a larger 'free area' per child of $\$ 12.30$ per week allowed under the PPS income test. In contrast, the free area allowed under the allowance income test does not vary with the number of children. As a result, a sole parent with three children and \$200 a week of earnings will be \$99 a week worse off under the proposed system compared with the current system. This compares with a $\$ 92$ a week loss for a sole parent with the same $\$ 200$ of earnings but only one child. 
Table 2: Impact of Proposed System on Disposable Incomes and EMTRs of Sole Parents: Various Levels of Earnings, 2006-07

\begin{tabular}{c|ccc|ccc}
\hline \multirow{2}{*}{ Private Income } & \multicolumn{3}{|c|}{ Disposable Income } & \multicolumn{3}{c}{ Effective Marginal Tax Rates } \\
\cline { 2 - 7 } & $\begin{array}{c}\text { Current } \\
\text { System }\end{array}$ & New System & Change* & $\begin{array}{c}\text { Current } \\
\text { System }\end{array}$ & New System & Change \\
\cline { 2 - 7 } & $\$ p w$ & $\$ p w$ & $\$ p w$ & per cent & per cent & $\begin{array}{c}\text { percentage } \\
\text { point }\end{array}$ \\
\multirow{2}{*}{ One child aged 6} & years and over & & & & & \\
\$0 & 385 & 356 & -29 & 0 & 0 & 0 \\
$\$ 50$ & 435 & 394 & -41 & 0 & 65 & 65 \\
$\$ 100$ & 476 & 411 & -64 & 40 & 65 & 25 \\
$\$ 150$ & 506 & 426 & -79 & 40 & 75 & 35 \\
$\$ 200$ & 531 & 439 & -92 & 57 & 75 & 18 \\
$\$ 300$ & 565 & 470 & -95 & 68 & 66 & -2 \\
$\$ 400$ & 597 & 504 & -93 & 68 & 66 & -2 \\
$\$ 500$ & 632 & 562 & -70 & 66 & 34 & -32 \\
$\$ 600$ & 656 & 629 & -27 & 66 & 50 & -16 \\
Two children aged & 6 years and over & & & & \\
$\$ 0$ & 468 & 439 & -29 & 0 & 0 & 0 \\
$\$ 50$ & 518 & 477 & -41 & 0 & 65 & 65 \\
$\$ 100$ & 563 & 494 & -69 & 40 & 65 & 25 \\
$\$ 150$ & 593 & 509 & -84 & 40 & 75 & 35 \\
$\$ 200$ & 617 & 522 & -96 & 57 & 75 & 18 \\
$\$ 300$ & 651 & 553 & -98 & 68 & 66 & -2 \\
$\$ 400$ & 683 & 587 & -96 & 66 & 66 & 0 \\
$\$ 500$ & 717 & 645 & -72 & 66 & 34 & -32 \\
$\$ 600$ & 750 & 714 & -36 & 78 & 30 & -48 \\
\hline
\end{tabular}

Note: Averaged 2006-07 payment levels used. All dollar figures rounded to nearest dollar. All EMTRs rounded to nearest one per cent. Time constraints prevented simulation of receipt by sole parent NSA recipients of PA. The PA has a particularly complicated income test and is non-taxable. To make a fair comparison between the current and proposed systems, PA was excluded from the calculations in both the current and proposed world. However, this exclusion makes little difference, as the payment is worth only $\$ 2.90$ a week and is received by sole parents in both the current and proposed systems if they are in receipt of income support. Thus, the difference between the two systems is in most cases not affected by this exclusion. The PA has also been excluded in Figures 1 to 2 .

For simplicity, in this Table and Figures 1 and 2, it is assumed that sole parents are not receiving child support. Child support is received in both the existing and proposed systems. It affects only Family Tax Benefit Part A entitlement, not income support payments, and makes no difference to the results

* Figures may not subtract exactly due to rounding.

Source: Specially created version of STINMOD/05A

\section{Impact of Proposed Changes on Effective Marginal Tax Rates}

When announcing the Welfare to Work Budget changes, the Minister noted that 'these changes are designed to assist, support and encourage parents to return to work when their children are old enough to go to school' (Andrews, 2005a). The effective marginal tax rate faced by sole parents affects their workforce incentives. 
An effective marginal tax rate (EMTR) measures how much of an additional dollar of earnings sole parents actually keep, after taking account of the various income tests associated with social security and family payments, the payment of income tax and the receipt of various tax allowances and rebates. An EMTR of 70 per cent means that the 'disposable' or 'take-home' income of a sole parent will increase by only 30 cents when earnings increase by $\$ 1$.

The EMTRs graph shown in Figure 2 take no account of the possible increased costs associated with rising earnings, such as increased transport or child care costs. They also take no account of possible 'knock on' effects to programs or services not administered by the Federal Government, such as rent payments for public housing tenants or State and local government concessions. As a result, the EMTRs can probably be regarded as being somewhat lower than those sole parents will face in the real world. As explained above, this is because we have at this stage probably over-estimated how much of each additional dollar of earnings many sole parents will actually retain to improve their and their children's welfare, primarily by taking no account of any increased costs associated with working.

Figure 2: EMTRs Facing Sole Parents with One Child 6 Years or Over Under Current and Proposed Systems, 2006-07

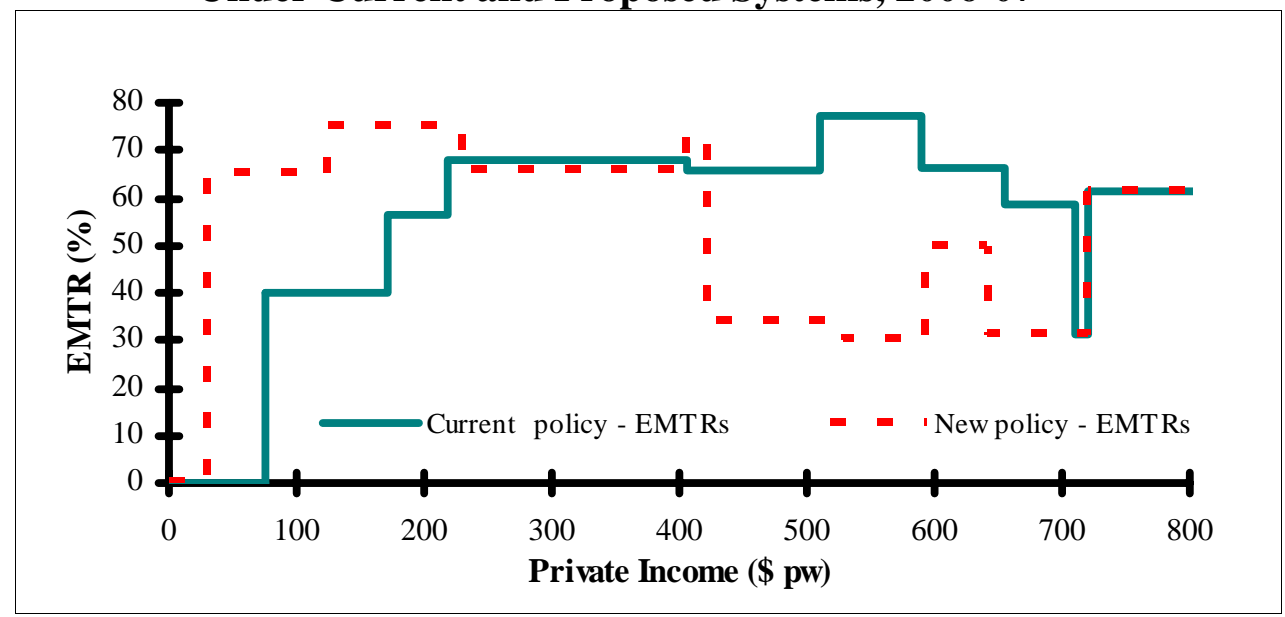

Source: Specially created version of STINMOD/05A. PA excluded from all calculations (see footnote to Table 2).

For sole parents with one child aged six years and over, the EMTRs faced at lower levels of private income (that is, earnings) are generally higher under the new system than under the existing system. Sole parents with weekly private incomes between around $\$ 31$ and $\$ 76$ a week face an EMTR of 65 per cent under the new system, compared with a zero EMTR under the current system. That is, for each additional dollar of earnings in this range, sole parents will keep only 35 cents under the new system, compared with 100 cents under the existing system.

Sole parents with one child with private incomes between $\$ 76$ a week and \$125 a week will also face substantially higher EMTRs under the proposed system 
- 65 per cent under the new system compared with only 40 per cent under the current system. That is, under the new system, sole parents with earnings in this range receive 25 cents less from each additional dollar of earnings than under the existing system.

Why do sole parents face a 65 per cent EMTR when their private income ranges between $\$ 31$ and $\$ 125$ a week under the proposed system (compared with either a 0 or 40 per cent EMTR under the current system)? This effect is due to 'income test stacking', with sole parents facing a 50 per cent EMTR due to the allowance income test plus a 15 per cent EMTR due to a combination of the effective withdrawal of the 'allowance tax offset' and the payment of income tax. The 'pensioner tax offset', in contrast, is withdrawn at the lesser rate of 12.5 per cent and only from a private income level which is almost five times higher than that for the beneficiary tax offset (\$31 of private income per week for allowance recipients versus $\$ 144$ of private income per week for sole parent pensioners). Thus, a less obvious implication of the proposed changes is that sole parents will be subject to the harsher allowance tax offset under the new system rather than the more generous pensioner tax offset which applies under the current system.

Private incomes between $\$ 125$ a week and $\$ 171$ a week are again subject to much higher EMTRs under the proposed system - 75 per cent under the new system compared with only 40 per cent under the existing system. Thus, relative to the proposed system, the current system allows sole parents to keep an extra 35 cents out of every additional dollar of income that they earn in this range. The particularly high EMTRs under the new system are due to the allowance withdrawal rate rising from 50 to 60 per cent, with this being stacked on top of the effective withdrawal of the allowance tax offset and the payment of income tax.

Under the NSA regime sole parents with a weekly income of just above $\$ 420$ cease receiving any allowance and their EMTRs fall to those facing standard taxpayers. Their EMTRs of 34 per cent consist of the 30 per cent payable through the standard income tax schedules plus the 4 per cent withdrawal of the Low Income Tax Offset (LITO). Once the LITO withdrawal finishes, their EMTRs remain at 30 per cent until they start paying the Medicare levy, at \$594 of private income. Where private incomes range from about $\$ 230$ to just over $\$ 400$, those sole parents under the existing system face marginally higher EMTRs than those under the proposed system, as sole parents under the existing system face one or more of the 40 per cent pension income test withdrawal, the 30 per cent tax rate, and the withdrawal of the LITO and the pensioner tax offset.

What do the higher EMTRs of sole parents with one child under the proposed regime mean in practical terms? Sole parents receiving NSA with private incomes ranging between $\$ 31$ a week and $\$ 420$ a week face EMTRs of 65 per cent or more. This is substantially higher than the top marginal income tax rate of 48.5 per cent (including Medicare levy) paid by the most affluent taxpayers in 2006-07 — that is, those whose taxable incomes exceed $\$ 125,000$ a year. As shown below, the impact of these high EMTRs is to ensure that the financial benefits from work are very low for sole parents receiving NSA. 
Proposed changes in industrial relations legislation make it difficult to predict the likely minimum wage in 2006-07. The recently announced minimum wage is $\$ 484$ for a 38-hour week. Suppose we assume that by 2006-07 it will have risen slightly to \$13 an hour. Suppose further that a sole parent with one child on NSA gets a 15-hour a week job that thus satisfies the proposed work obligations and for which the pay is $\$ 195$ a week ( $\$ 13$ an hour multiplied by 15 hours). Under the current system, this sole parent will keep $\$ 144$ of this $\$ 195$, thus gaining a substantial increase in disposable income by moving from no paid work to 15 hours of paid work. Under the proposed system, this sole parent will experience only an $\$ 81$ a week increase in take-home income. The Federal government will become the major beneficiary of the sole parent's move to 15 hours of paid work a week and will get $\$ 114$, via the reduced NSA and increased income tax.

The retention of an additional $\$ 81$ a week by the sole parent after earnings rise to $\$ 195$ a week assumes that the costs of work are zero. If additional transport, clothing, lunch and other costs were actually, say, \$30 a week when moving from zero to 15 hours paid work a week, then the gains to this sole parent family would fall further to $\$ 51$ a week.

In addition, as noted earlier, there may be 'knock on' effects to other incometested programs. For example, using the 1996 Census data, Burke, Aspin and Short (2001) showed that 16 per cent of sole parent families lived in public housing. They also noted the work disincentives faced by public housing tenants, who lose 25 per cent of their earnings through increases in the rent that they have to pay (that is, there is an effective 25 per cent taper in the public housing rent rebate formulas). In the example above, therefore, a sole parent in public housing could lose a further $\$ 20$ of the $\$ 81$ increase in disposable income through the higher rent. Again, if the costs of work amounted to, say, $\$ 30$ a week, then the net gain by the sole parent from 15 hours of work would fall to $\$ 31$ a week. This is an effective pay rate of about $\$ 2$ an hour.

\section{Sole parents with two or three children}

The results for sole parents with two or three children are very similar. The only key change is that under the existing pension income test, an additional $\$ 12.30 \mathrm{a}$ week of earnings is disregarded for each additional child after the first. This slightly extends the zone of private income in which these sole parents face a zero EMTR, relative to sole parent pensioners with one child. In contrast, the point at which sole parents on NSA start facing EMTRs of 65 per cent does not vary with the number of children, remaining at $\$ 31$ a week of private income. Sole parents with two or more children are therefore somewhat more disadvantaged than those with only one child by the proposed move from the pension to the allowance income test regime. The extent of relative disadvantage increases with the number of children: sole parent pensioners with five children can earn \$125 a week of private income before facing the 40 per cent EMTR caused by the pension income test, whereas sole parent allowance recipients with five children can earn only \$31 
a week of private income before facing the 65 per cent EMTR caused by the allowance income test and increased taxes.

\section{Labour Market Issues}

As noted earlier, one of the concerns that the welfare to work changes are trying to address is the lower labour force participation rates of sole parents on welfare. Table 3 shows that in 2002-03, 59 per cent of partnered mothers with dependent children were working and 34 per cent were working part-time. Looking first at all sole parents, 49 per cent were working, with 24 per cent working part-time. However, looking only at the subset of sole parents who are receiving PPS, only 35 per cent are working, with 27 per cent of these being part-time. Thus, comparing sole parents receiving PPS with partnered mothers, the difference in their labour force participation rates is 24 per cent, with the big difference being the proportion working full-time. Since 1995-96 the gap between the labour force participation rates of partnered mothers and PPS recipients has narrowed, with the proportion of partnered mothers working falling by two percentage points and the proportion of PPS recipients with jobs increasing by six percentage points.

Table 3: Labour Force Characteristics of Those with Children 0-14 Years, 2002-03

\begin{tabular}{l|cc|ccc}
\hline & \multicolumn{2}{|c|}{$1995-96$} & \multicolumn{3}{c}{ 2002-03 } \\
& Work & Work & Work & Work & With Job-No \\
& Full-time & Part-time & Full-time & Part-time & Post-school Quals \\
\hline Partnered mothers & 28 & 33 & 25 & 34 & 41 \\
All sole parents & 28 & 20 & 25 & 24 & 39 \\
Sole parents receiving PPS & 4 & 25 & 8 & 27 & 53 \\
\hline
\end{tabular}

Source: Calculated from 2002-03 and 1995-96 ABS Survey of Income and Housing Costs confidentialised unit record files.

It is clearly more difficult to work full-time as a sole parent, when caring responsibilities cannot be shared with another parent. But there are also other important differences between partnered mothers and Parenting Payment Single recipients. Just over half of all PPS recipients in 2002-03 are not in the labour force and a striking 80 per cent of these have no post-school qualifications. In contrast, just under two-fifths of all partnered mothers are not in the labour force and 62 per cent of these have no post-school qualifications. Overall, 67 per cent of all PPS recipients have no post-school qualifications, compared with only 45 per cent of partnered mothers.

There is a clear link between qualifications and the likelihood of having a job with, for example, partnered mothers with bachelor degrees being twice as likely in 2002-03 as partnered mothers with no qualifications to hold a full-time job. This is partly linked to the financial rewards from paid work being greater for workers with additional educational qualifications, as they can command a higher 
pay rate. Given that PPS recipients are much more likely than partnered mothers to have only school qualifications, it is probably unrealistic to expect the participation rates of the two groups to be the same.

As noted above, four-fifths of those PPS recipients who are not in the labour force and are thus the particular target of the proposed welfare to work changes do not have any post-school qualifications. The hourly wage rates received by those PPS recipients who do have a job provide us with some guide to the likely hourly wage rates that those currently out of the labour force will be likely to receive.

In 2002-03, of all those PPS recipients with children aged 0 to 14 years who reported wage and salary income, the overwhelming majority (77 per cent) received hourly wage rates between $\$ 10$ and $\$ 20$ an hour - with the average wage for those in this band being $\$ 14.70$ an hour. ${ }^{1}$ These estimates are for 200203, so that wages could be expected to be higher by 2006-07. But, those PPS recipients who currently do have a job are better educated than those who don't, so that the wage rates that the potential new entrants to paid work will command will probably be lower. Overall, the example given in the preceding section of the impact of the welfare to work changes on a sole parent working 15 hours for \$13 an hour appears to be a reasonable approximation for what will happen to many PPS recipients who take up paid work after the proposed system is introduced.

Figure 3: Distribution of wage/salary earnings: Parenting Payment Single Recipients with Children 0 to 14 years, 2002-03

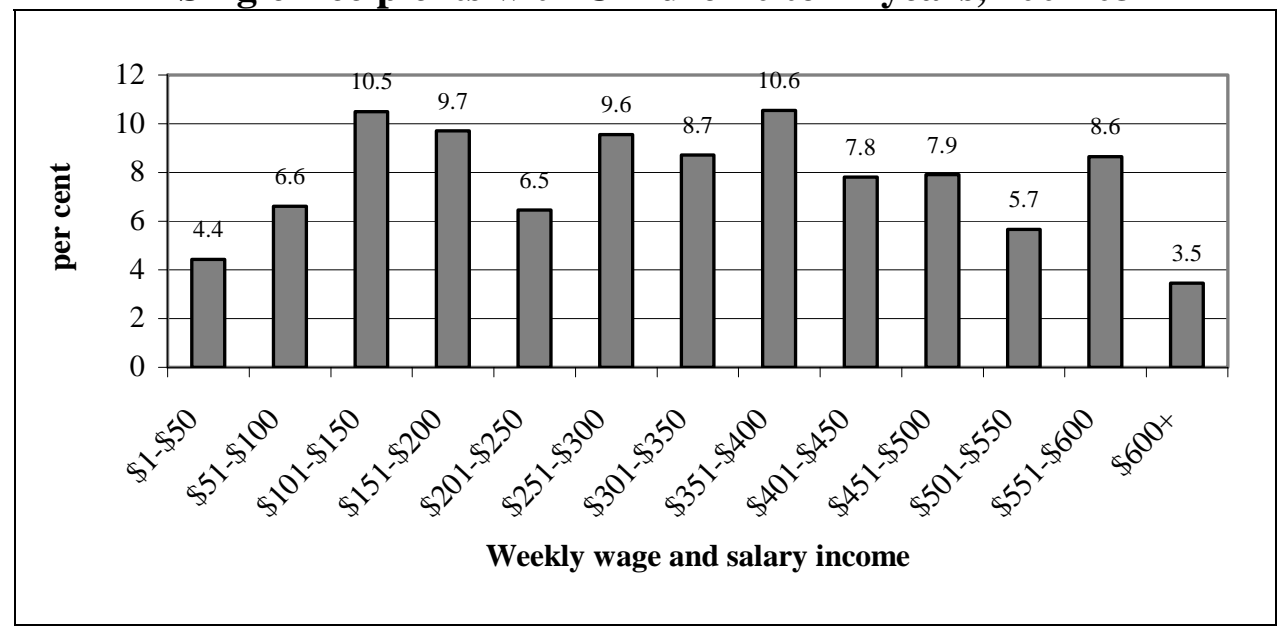

Note: The graph refers only to PPS recipients who have children aged 0 to 14 years and report more than $\$ 1$ a week of wage and salary income.

Source: Calculated from 2002-03 ABS Survey of Income and Housing Costs confidentialised unit record files.

1 Estimates were derived from the 2002-03 ABS Survey of Income and Housing Costs confidentialised unit record file. As the ABS reports weekly hours worked in small bands only (for example, 6-7 hours), the bands' midpoints were used to calculate hourly rates. 
Figure 3 shows the current distribution of earnings of PPS recipients with children aged 0-14 years and with wage and salary income. Of this group, 34 per cent work 12-21 hours a week for those earnings and about one-fifth report wage and salary income of $\$ 150$ or less a week. A further 10 per cent report earnings of between $\$ 150$ and $\$ 200$ a week. While many are no doubt working less than 15 hours a week, these are roughly the earnings zones in which much higher EMTRs will be faced under the proposed system. Overall, 67 per cent report earnings of less than $\$ 400$ a week, roughly corresponding to the earnings range that will attract EMTRs of 65 per cent or more under the proposed system. Conversely, only one-third report earnings of more than $\$ 400$ a week.

\section{Conclusions}

The Government's proposed welfare to work reforms will not directly affect the distributional income or effective marginal tax rates (EMTRs) of those sole parents who are already in receipt of PPS on 1 July 2006 and who remain on that payment. Such sole parents will face new work obligations if their youngest child is aged six years or more, but they will not be placed on NSA until their youngest child reaches the age of 16 years.

However, sole parents who begin receiving income support after 1 July 2006 will be placed on PPS if their youngest child is aged less than six years - but on NSA if (or as soon as) their youngest child reaches the age of six years.

The NSA maximum payment rate is about $\$ 29$ a week lower than that of PPS, resulting in an immediate loss of this amount of income for those transferred from PPS to NSA when their youngest child turns six. The NSA income test is also much less generous than the PPS income test and the tax treatment of allowance recipients is much less generous than the income tax treatment of pensioners. For sole parents with one child and around $\$ 230$ per week of private earnings, who are transferred to NSA, the effect of these tests is that the losses in take-home income can be as high as $\$ 96.50$ a week.

For example, a sole parent with one child who is working 15 hours a week for a pay rate of $\$ 13$ an hour will have a take-home income each week of $\$ 437$ under the NSA rules. In contrast, the same sole parent would take home \$529 a week under the current PPS rules. This sole parent, with one child and earnings of \$195 a week, will thus be $\$ 92$ a week worse off under the proposed system than under the current system.

Under the proposed system, the Federal government will be the major beneficiary of such a sole parent moving from zero to 15 hours a week of paid work, with the sole parent keeping $\$ 81$ a week of their $\$ 195$ a week of earnings, and the government taking the other $\$ 114$, via reduced NSA and increased income tax payments.

The maximum losses experienced by sole parents under the proposed system relative to the current system increase with the number of children. For example, for sole parents with five children, the maximum losses reach up to \$107 a week for those with private incomes ranging from about \$215 to \$290 a week. 
The related consequence of the more restrictive NSA income test and harsher income tax treatment is to create much higher effective marginal tax rates for sole parents than they face under the current PPS income test. Sole parents with one child aged 6 to 12 years will face EMTRs of 65 per cent or more over a broad band of private income ranging from \$31 to about \$229 a week under the proposed system. In contrast, under the current system, such sole parents face a zero EMTR for private incomes between \$31 and \$76 a week, and only a 40 per cent EMTR for private incomes between $\$ 76$ and $\$ 171$ a week. The effect of these income test and tax changes is thus to reduce the attractiveness of paid work to sole parents - and to reduce the amount of income that they have available to support themselves and their children after they undertake paid work.

As the analysis of the current earnings of PPS recipients suggests, the majority of those sole parents who enter the labour market while receiving NSA appear likely to have earnings that will attract EMTRs of 65 per cent or more.

The need to increase the number of workers as our population ages and the long-term improvements in economic well-being that occur with ongoing workforce participation are some of the factors that lie behind the Federal Government's proposed changes. Many policy analysts will not object to the goal of increasing the labour force participation of sole parents, although they may wish to debate specific aspects of the proposed policies, such as:

- $\quad$ whether the 'age of youngest child' that triggers the compulsory work requirements should be higher than six years;

- whether there should be special measures for those sole parents trying to raise large families by themselves; or

- whether there should be exemptions for sole parents raising disabled children.

However, perhaps of more concern is that our analysis suggests that sole parents will be required to undertake paid work while also being placed on an income support regime that will ensure that many receive minimal improvements in the financial position of their family from that paid work. In addition, the dramatic drop in income that will occur almost overnight for many sole parents when their youngest child turns six would seem likely to have an adverse effect on the wellbeing of the children, as well as their parents. While it is to be hoped that in the longer term many children will be living in sole parent families whose incomes are higher as a result of the expected increases in paid work, in the shorter term many children will be living in sole parent families whose incomes are much lower than under the current income support rules.

These concerns could be overcome by allowing sole parents to remain on the existing PPS, rather than transferring them to NSA when their youngest child turns six. Thus, the government's key goal of encouraging sole parents to work could still be achieved via some form of paid work obligation, but sole parents could remain on an income support payment regime that ensured that they and their children were financially much better off after undertaking paid work. 
While the particular focus of this paper has been sole parents, others on NSA also face the high effective marginal tax rates discussed in this paper. Indeed, the proposed NSA income test analysed in this paper is more liberal than the current NSA income test (which has a 70 cents in the dollar taper for each dollar of private income over $\$ 71$ a week, versus a 60 cents in the dollar taper for each dollar of private income above $\$ 125$ a week in the proposed system). Thus, the Government has responded to the continuing concerns about the impact of high effective marginal tax rates on work incentives by liberalising the income test for NSA recipients from 1 July 2006. Nonetheless, poverty traps remain an on-going issue for many income support recipients. However, until now sole parents have benefited from being placed on the more liberal 'pension' regime, in recognition of the longer-term responsibilities associated with being the primary and sole carer of children.

\section{References}

Andrews, K. (2005a), 'Welfare to Work - Increasing Participation of Parents', Budget 2005-06, Office of the Hon Kevin Andrews MP, Parliament House, Canberra.

Andrews, K. (2005b), 'Welfare to Work - Improved Returns from Work for People Receiving Allowance', Budget 2005-06, Office of the Hon Kevin Andrews MP, Parliament House, Canberra.

Australian Bureau of Statistics (2000), 'Labour Force Status and Other Characteristics of Families, Australia', (Cat No 6224.0), http://www.abs.gov.au/ausstats.

Australian Bureau of Statistics (2004), 'Family Characteristics, Australia', (Cat No 4442.0), http://www.abs.gov.au/ausstats.

Barrett, G. (2001), 'The Dynamics of Participating in Parenting Payment (Single) and the Sole Parent Pension', Policy Research Paper No 14, Department of Family and Community Services, Canberra.

Bradbury, B. (2003), 'Child Poverty: A Review', Policy Research Paper No 20, Department of Family and Community Services, Canberra.

Burgess, S. and C. Propper (1998), 'Early Health Related Behaviours and Their Impact on Later Life Chances: Evidence from the US’, Health Economics 7(5):381-99.

Burke, T., R. Aspin and H. Short (2001), 'Sole Parents, Social Wellbeing and Housing Assistance', work in progress report for the Australian Housing and Urban Research Institute, http://www.ahuri.edu.au.

Goodger, K. and P. Larose (1998), 'Changing Expectations: Sole Parents and Employment in New Zealand', 6th Australian Institute of Family Studies Conference, http://www.aifs.gov.au.

Gregory, R. and E. Klug (2003), 'A Picture Book Primer: Welfare Dependency and the Dynamics of Female Lone Parent Spells', Australian National University, http://econrsss.anu.edu.au/Staff/gregory/pdf/PictureBookPrimer_17_01_03_Facs.pdf. 
Kelly, S. and A. Harding (2002), 'Income and Wealth of Those About to Retire', AMP.NATSEM Income and Wealth Report, Issue No. 2, May, http://www.amp.com.au/ampnatsemreports.

Kelly, S. and A. Harding (2005) 'Love Can Hurt, Divorce Will Cost: The Financial Impact of Divorce in Australia’, AMP.NATSEM Income and Wealth Report, Issue No. 10, April, http://www.amp.com.au/ampnatsemreports.

Kelly, S., C. Farbotko and A. Harding (2004), 'The Lump Sum: Here Today, Gone Tomorrow', AMP.NATSEM Income and Wealth Report, Issue No. 7, March, http://www.amp.com.au/ampnatsemreports.

Kelly, S., R. Percival, and A. Harding (2002), 'Women and Superannuation in the $21^{\text {st }}$ Century: Poverty or Plenty?’, pp. 223-249 in Competing Visions, Proceedings of the National Social Policy Conference, SPRC Report 1/02, University of New South Wales.

McColl, B, L. Pietsch and J. Gatenby (2002), 'Household Income, Living Standards and Financial Stress', pp. 198-209 in Year Book Australia 2002, Australian Bureau of Statistics, Canberra.

Moore, K., D. Glei, A. Driscoll, M. Zaslow and Z. Redd (2002), 'Poverty and Welfare Patterns: Implications for Children’, Journal of Social Policy 31(2):207-27.

Poulton, R., A. Caspi, B. Milne, W. Thompson, A. Taylor, M. Sears and T. Moffitt (2002), 'Association Between Children's Experience of Socioeconomic Disadvantage and Adult Health: a Life-Course Study’, The Lancet 360(23 November):1640-45.

Productivity Commission (2005), Economic Implications of an Ageing Australia, Research Report, Canberra.

Saunders, P. and K. Tsumori (2003), 'The Tender Trap: Reducing Long-term Welfare Dependency by Reforming the Parenting Payment System’, Issue Analysis No. 36, Centre for Independent Studies, Sydney, http://www.cis.org.au.

Treasury (2002), Budget Paper No. 5, Intergenerational Report 2002-03, Department of the Treasury, Canberra, May.

UNICEF (2000), A League Table of Child Poverty in Rich Nations, UNICEF, Florence.

Wilson, K, J. Pech and K. Bates (1999), 'Parents, the Labour Force and Social Security', Policy Research Paper No. 2, Department of Family and Community Services, Canberra.

The authors gratefully acknowledge the financial support provided for this study by the National Foundation for Australian Women and University of Canberra. 